\title{
PERAN DOSEN MATA KULIAH PENDIDIKAN PANCASILA DAN KEWARGANEGARAAN DALAM MENINGKATKAN RASA NASIONALISME MAHASISWA
}

\author{
Toni Anwar Mahmud ${ }^{1}$, Tajudin Hasan ${ }^{2}$, \\ Universitan Banten Jaya \\ Serang, Indonesia \\ tajudinhasan63@gmail.com¹ ,toniam@unbaja.ac.id ${ }^{2}$, alamsyahbasri74@gmail.com³
}

\begin{abstract}
This research is done because the number of students of UNBAJA's PPKn courses semester II and IV academic year 2017 - 2018 have low nationalism.. This was seen from the results of tests that showed that there were still many students of the UNBAJA's PPKn courses in the second and fourth semester of the 2017-2018 academic year who did not memorize the Pancasila and Indonesian Raya, and did not understand the meaning of Bhinneka Tunggal Ika. The purpose of this study was to determine the causes of the low sense of nationalism of students in the UNBAJA's PPKn courses in the second and fourth semester of 2017 - 2018 academic year and to find out the role of lecturers of PPKn courses in increasing the nationalism feeling of students in the UNBAJA's PPKn courses in the second and fourth semester of 2017 - 2018. This study uses a descriptive method of qualitative approach with data collection techniques using test techniques, observation and interviews. Subjects of this study are lecturers of UNBAJA's PPKn courses and students of UNBAJA's PPKn courses in second and fourth semester of academic year 2017 - 2018. The results of this study indicate that the role of the PPKn lecturer can increase the sense of nationalism of students in the PPKn UNBAJA courses in the second and fourth semester of the 2017 - 2018 academic year, such as before the teaching and learning activities are conducted in class, the lecturer always instructed everyone to pray.
\end{abstract}

Keywords: Nationalism, Role of PPKn Lecturer, Increasing Nationalis.

\section{PENDAHULUAN}

Nasionalisme adalah sikap rasa cinta terhadap tanah air yang tidak hanya dikatakan dengan lisan saja, akan tetapi juga dibarengi dengan tindakan yang mencerminkan seseorang cinta terhadap tanah air, seperti dengan mencintai adanya perbedaan yang ada di Indonesia. Dalam penumbuhan rasa nasionalisme peran pendidik sangat diperlukan, dosen selaku pendidik dikalangan mahasiswa harus berperan aktif dalam hal ini karena pada selayaknya seorang pendidik, dosen harus berupaya untuk meningkatkan rasa nasionalisme dikalangan mahasiswa yang dewasa ini mengalami penurunan. Melalui Pendidikan Pancasila dan Kewarganegaraan (PPKn) seseorang dapat belajar agar mempunyai jiwa nasionalisme, Pendidikan Pancasila dan Kewarganegaraan (PPKn) adalah disiplin ilmu yang bersifat nasional karena sudah 
jelas tertera nama "Pancasila" yang dimana hanya di Indonesia saja yang berpedoman pada Pancasila. Mengenai hal tersebut sangatlah erat kaitannya dengan nasionalisme, banyak pandanganpandangan menurut ahli mengenai arti dari nasionalisme yang mencakup berbagai aspek yang menandakan seseorang cinta terhadap tanah air atau mempunyai jiwa nasionalisme yang tinggi, wujud dari nasionalisme yang terkecil pun bisa melalui beberapa hal. Pertama mengenai Pancasila, menurut

Yudi Latif dalam kutipan perkataan Soekarno, 1958 (2011 : 1) yang mengatakan bahwa "Pancasila adalah satu alat mempersatu, yang saya yakin seyakinyakinnya bangsa Indonesia dari Sabang sampai Merauke hanya dapat bersatupadu diatas dasar Pancasila itu. Kedua menjaga keutuhan Negara Kesatuan Republik Indonesia (NKRI), hal ini sangatlah vital atau bisa dikatakan sebagai tanda dimana seorang warga negara jika ia sudah mempunyai jiwa nasionalisme yang tinggi pasti akan mempunyai kesadaran untuk berkewajiban menjaga negaranya sendiri, salah satu contoh cara menjaga nilai dengan lagu kebangsaan Indonesia Raya, setiap negara pasti memiliki laku kebangsaan, dan bukan hanya sekedar lagu yang lebih mementingkan keindahan semata, akan tetapi merupakan sebuah ungkapan harapan dan cita-cita nasional, yang dimana dalam lagu tersebut terdapat semangat nasionalisme sebagai pemersatu bangsa Indonesia, dan tidak dapat dipungkiri pada jaman perebutan kemerdekaan, sebuah lagu terlebih lagi lagu kebangsaan yang tentunya dapat menjadikan sebuah penyemangat diri dan setiap warga negara untuk merebut kemerdekaan. Ketiga mengenai arti dari Bhineka Tunggal Ika, sebuah kalimat bahasa Jawa kuno yang berasal dari kitab sutasoma karangan mpu Tantular, dan jika diartikan kedalam bahasa Indonesia adalah "berbeda- beda tetapi tetap satu". Menurut Yudi Latif, (2017:272-305) menyebutkan bahwa :"Nasionalisme dalam kesadarannya dapat dibagi tiga bagian, pertama kesadaran nasionalisme purba (Archaic Nationalism), yaitu suatu bentuk kesadaran nasionalisme "negatif" (defensif) dalam skala terbatas yang pada umumnya dibangkitkan dengan menggunakan simbolisme dan jaringan keagamaan yang berimpitandengan etnisitas. Kedua, kesadaran nasionalisme tua, adalah suatu rasa yang muncul akibat kejayaan masa lalu sebuah bangsa. Ketiga, nasionalisme modern ialah pergulatan dari berbagai nilai-nilai perjuangan masyarakat diberbagai tempat, seperti pada peristiwaperistiwa sejak awal kependudukan Jepang yang merupakan awalan bagi sebuah perubahan besar dalam sejarah kemerdekaan bangsa Indonesia". Sejalan 
dengan teori Adolf Heuken dalam Hamidi (2010:168) yang menyatakan bahwa nasionalisme sebagai pandangan yang berpusat pada bangsanya.

Menurutnya, kata nasionalisme mempunyai dua arti. Pertama, dalam arti nasionalistis merupakan suatu sikap yang keterlaluan, sempit, dan sombong. Sikap nasionalistis menunjukkan tidak menghargai orang lain seperti semestinya. Apa yang menguntungkan bangsa sendiri dianggap benar begitu saja, meskipun hal itu akan menginjak-injak hak dan kepentingan bangsa lain. Kedua, yakni nasionalisme positif, merupakan sikap yang memperjuangkan dan mempertahankan kemerdekaan serta harga diri bangsa sekaligus menghormati bangsa lain.

Semua konsepsi tersebut terdapat pada empat pilar kebangsaan yang meliputi : pertama adalah Pancasila, yaitu suatu konsepsi tentang dasar negara dan dijadikan sebagai dasar dan ideologi bangsa dengan merangkum lima prinsip utama atau sila yang menyatukan Indonesia yang dikenal sebagai Pancasila. Kedua Undang-Undang Dasar Negara Republik Indonesia tahun 1945 sebagai hukum dasar, merupakan kesepakatan umum warga negara mengenai norma dasar dan aturan dasar dalam kehidupan bernegara.
Kesepakatan ini utamanya menyangkut tujuan dan cita-cita bersama, the rule of law sebagai landasan penyelenggaraan negara, serta bentuk instutusi dan prosedur ketatanegaraan. Ketiga Negara Kesatuan Republik Indonesia (NKRI), Konsepsi tentang bentuk negara Indonesia menganut bentuk negara kesatuan yang menjunjung tinggi otonomi dan kekhususan daerah sesuai dengan budaya dan adat istiadatnya.

Keempat Bhineka Tunggal Ika (meskipun berbeda-beda, tetap satu jua), disatu sisi ada wawasan "ke-eka-an" yang berusaha mencari titik temu dari segala kebhinekaan yang terkristalisasikan dalam dasar negara (Pancasila), UndangUndang Dasar dan segala turunan perundang- undangannya, negara persatuan, dan simbol-simbol kenegaraan lainnya.

\section{METODE PENELITIAN}

Tempat penelitian skripsi ini dilakukan di kampus 1 (satu) Universitas Banten Jaya (UNBAJA) tepatnya di Jl. Ciwaru Raya II No.73 Warung Pojok, Serang-Banten, dan kampus II (dua) yang bertempat di Jl. Syeh Nawawi Al-Bantani KP3B, SerangBanten. Adapun untuk waktu penelitian nya itu sendiri dimulai dari tanggal 07 sampai dengan 31 bulan Mei tahun 2018 . Dalam penelitian ini penulis mendapatkan 
data dari beberapa informan, Informan yang dipilih dalam penelitian ini adalah pihak-pihak yang terlibat dalam meningkatkan rasa nasionalisme mahasiswa Pendidikan Pancasila dan Kewarganegaraan (PPKn) Universitas Banten Jaya (UNBAJA) semester II (dua) dan IV (empat) tahun ajaran 2017-2018 yang dimulai dari tahapan mencari data mahasiswa Pendidikan Pancasila dan Kewarganegaraan (PPKn) Universitas Banten Jaya (UNBAJA) semester II (dua) dan IV (empat) tahun ajaran 2017-2018.

Hal tersebut sesuai dengan teknik penentuan informan dengan cara purposive dimana informasi didapat dari staf Fakultas Keguruan dan Ilmu Pendidikan (FKIP) Universitas Banten Jaya (UNBAJA) yang diperlukan dalam penelitian. Kemudian dengan pertimbangan kebutuhan data yang relevan dengan permasalahan penelitian, jumlah informasi dibatasi dengan anggapan triangulasi data menitikberatkan pada kejenuhan data atau data yang sifatnya berulang. Subjek penelitian ini adalah dosen mata kuliah Pendidikan Pancasila dan Kewarganegaraan, mahasiswa PPKn UNBAJA semester II dan IV tahun ajaran 2017-2018, beberapa staf kampus dan beberapa alumni mahasiswa program studi Pendidikan Pancasila dan Kewarganegaraan.

Tujuan penelitian ini untuk mengetahui penyebab rendahnya rasa nasionalisme mahasiswa program studi PPKn UNBAJA semester II dan IV ajaran 2017-2018 dan peran penting dosen mata kuliah PPKn dalam meningkatkan rasa nasionalisme mahasiswa program studi PPKn UNBAJA semester II dan IV tahun ajaran 2017-2018.

Dari pra penelitian tersebut diambil sampel sebanyak 20 orang mahasiswa dari jumlah total 53 orang mahasiswa program studi Pendidikan Pancasila dan Kewarganegaraan (PPKn) Universitas Banten Jaya (UNBAJA) semester II (dua) dan IV (empat) tahun ajaran 2017-2018, menghasilkan data bahwa 11 mahasiswa diantaranya tidak hafal secara lancar akan Pancasila, 16 mahasiswa tidak lancar dalam menyanyikan lagu Indonesia Raya, dan 8 mahasiswa kurang memahami akan arti dari Bhineka Tunggal Ika.

Berdasarkan penjelasan di atas, maka Penulis merasa tertarik untuk mengadakan penelitian dengan judul "Peran Dosen Mata Kuliah Pendidikan Pancasila dan Kewarganegaraandalam Meningkatkan Rasa Nasionalisme Mahasiswa” (Mahasiswa Program Studi PPKn UNBAJA Semester II dan IV Tahun Ajaran 2017- 2018)". Metode yang digunakan adalah metode deskriptif pendekatan kualitatif dengan teknik pengambilan data menggunakan teknik tes, 
observasi dan wawancara.

Menurut Moleong (2013:6) penelitian kualitatif adalah penelitian yang bermaksud untuk memahami fenomena tentang apa yang dialami oleh subjek penelitian misalnya prilaku, persepsi, motivasi, tindakan, dll.

Adapun teknik pengumpulan untuk memperoleh data yang relevan dengan masalah yang diteliti, dilakukan dengan cara sebagai berikut :

Observasi, Menurut Sugiyono dalam Sutrisno Hadi (1986:203) mengemukakan bahwa, observasi merupakan suatu proses yang kompleks, suatu proses yang tersusun dari berbagai proses biologis dan psikhologis. Penelitian ini bertujuan untuk memperoleh informasi-informasi mengenai keadaan yang ada, dengan mencari data dan fakta mengenai penyebab dan solusi untuk meningkatkan rasa nasionalisme mahasiswa PPKn UNBAJA semester II dan IV tahun ajaran 2017-2018. Tes, menurut Arikunto (2010:266) tes merupakan teknik pengumpulan data yang digunakan untuk mengukur kemampuan dasar dan pencapaian atau prestasi.

Dalam penelitian skripri ini penulis melakukan tes kepada mahasiswa program studi Pendidikan Pancasila dan Kewarganegaraan (PPKn) Universitas Banten Jaya (UNBAJA) semester II (dua) dan IV (empat) tahun ajara 2017-2018 berupa hafalan Pancasila, lagu Indonesia Raya, dan pemahaman mengenai Bhineka Tunggsal Ika. Sampling, dalam penelitian skripsi ini penulis menggunakan sampling purposive atau sampel bertujuan. Maksud dari sampling bertujuan dalam penelitian ini adalah bahwa penulis hanya meneliti mahasiswa program studi PPKn UNBAJA semester II dan IV ajaran 2017-2018 yang aktif dalam perkuliahan, hal itu dibuktikan dari daftar absensi kelas.

Menurut Moleong mengatakan bahwa :“...dalam penelitian kualitatif sangat erat kaitannya dengan faktor-faktor kontekstual. Jadi, maksud sampling dalam hal ini ialah untuk mendapatkan sebanyak mungkin informasi dari pelbagai macam sumber dan bangunannya (contructions).

Dapat disimpulkan bahwa tujuannya bukanlah untuk memusatkan diri pada adanya perbedaan-perbedaan yang nantinya dikembangkan kedalam generalisasi. Tujuannya adalah untuk merinci kekhususan yang ada dalam konteks yang unik. Maksud kedua dari sampling adalah untuk menggali informasi yang akan menjadi awal atau dasar dari rancangan dan teori yang muncul.

Wawancara, menurut Hasan (2002:85) adalah teknik pengumpulan data dengan mengajukan pertanyaan langsung oleh pewawancara kepada responden, dan 
jawaban-jawaban responden dicatat atau direkam. Penulis melakukan wawancara kepada dosen mata kuliah Pendidikan Pancasila dan Kewarganegaraan, mahasiswa PPKn UNBAJA semester II dan IV tahun ajaran 2017-2018, beberapa staf kampus dan beberapa alumni mahasiswa program studi Pendidikan Pancasila dan Kewarganegaraan.

Dokumentasi, menurut Arikunto, (2010:274) dokumentasi adalah mencari data mengenai hal-hal atau variabel yang berupa catatan, transkip, buku, surat kabar, majalah, prasasti, notulen rapat, lengger, agenda, dan sebagainya.

Dokumentasi yang dilakukan penulis dalam penelitian skripsi ini dilakukan secara langsung dan bertujuan untuk memperkuat data yang ada. Demi terjaminnya keakuratan data, maka penulis melakukan keabsahan data yang bertujuan untuk menyatakan bahwa penelitian ini dilakukan dengan data yang akurat sesuai dengan kondisi pada saat melakukan penelitian.

\section{Menurut Moleong}

$(2013: 324)$ menyatakan bahwa untuk menetapkan keabsahan (trustworthiness) data diperlukan teknik pemeriksaan. Pelaksanaan teknik pemeriksaan didasarkan atas sejumlah kriteria tertentu. Ada empat kriteria yang digunakan, yaitu derajat kepercayaan (credibility), keterahlian (dependability)dan kepastian (confirmability). Pada penelitian ini, analisis data yang digunakan adalah pendekatan kualitatif dengan observasi yang dimana sebelumnya sudah dilakukan pra penelitian untuk mengetahui informasi secara nyata terhadap permasalahan yang terjadi.

Menurut Moleong dalam Bogdan \& Biklen (1982:248) menyatakan bahwa : Analisis data kualitatif adalah upaya yang dilakukan dengan jalan bekerja dengan data, mengorganisasikan data, memilahmilahnya menjadi satuan yag dapat dikelola, mensintesiskannya, mencari dan menemukan pola, menemukan apa yang penting dan apa yang dipelajari, dan memustuskan apa yang dapat diceritakan kepada orang lain.

Sementara itu, pendapat mengenai analisis data juga dikemukakan menurut Sugiyono (2013:335) yang menyatakan bahwa analisis data adalah proses mencari dan menyusun secara sistemasis data yang diperoleh dari hasil wawancara, catatan dilapangan, dan dokumentasi, dengan cara mengelompokkan data kedalam kategori, menjabarkan kedalam unit-unit, melakukan sintesa, menyusun ke dalam pola, memilih mana yang penting dan yang akan dipelajari, dan membuat kesimpulan sehingga dapat di pahami dengan mudah oleh diri sendiri maupun orang lain.

HASIL PENELITIAN DAN 


\section{PEMBAHASAN}

Hasil dalam penelitian ini dapat disimpulkan dan berdasarkan dari penelitian yang telah dilakukan oleh penulis yang menemukan hasil temuan bahwa rendahnya rasa nasionalisme pada mahasiswa program studi PPKn UNBAJA semester II dan IV tahun ajaran 2017-2018 disebabkan kerena adanya beberapa faktor yang menyebabkan rendahnya rasa nasionalisme pada mahasiswa program studi PPKn UNBAJA semester II dan IV tahun ajaran 2017-2018.

Dikaitkan dengan teori dari Hans Kohn (1984 : 11) yang menyatakan bahwa nasionalisme adalah suatu paham, yang berpendapat bahwa kesetiaan tertinggi individu harus diserahkan kepada negara kebangsaan.

Dapat disimpulkan bahwa mahasiswa program studi PPKn UNBAJA semester II dan IV belum mempunyai rasa nasionalisme yang tinggi. Hal tersebut disebabkan karena adanya beberapa factor yang mempengaruhinya faktor tersebut berasal dari faktor pribadi yang enggan atau tidak ada kemauan dari diri mahasiswa sendiri untuk mengetahui dan memahami mengenai nasionalisme, rendahnya semangat belajar pada diri mahasiswa, tidak adanya motivasi diri, tidak adanya kemauan untuk menggali diri, rendahnya pengetahuan terhadap pendidikan, bersikap individualis. Faktor lingkungan keluarga yang kurang memberikan contoh teladan,orang tua atausalah satu anggota keluarga (orang dewasa) yang tidak mencerminkan memiliki rasa nasionalismemaka berpotensi besar akan di contoh pula oleh anggota keluarga lainnya. Faktor lingkungan tempat tinggal yang tidak mencerminkan nasionalisme, rasa nasionalisme seperti gotong royong, dan teman bermain yang terbiasa dengan berpakaian atau pun bertingkah laku layaknya budaya asing akan mempengaruhi dalam tingkatan rasa nasionalisme seseorang. Faktor perkembangan globalisasi yang dirasa sangat besar dampaknya pada keadaan sekarang ini yang dapat mengancam jati diri bangsa dapat mengancam jati diri bangsa. Kebanyakan orang lebih cenderung melakukakan hal negatif seperti gaya berbicara layaknya orang asing, bertingkah laku yang tidak mencerminkan adanya norma kesopanan, serta berpakain mencontoh budaya asing yang belum tentu sesuai dengan budaya yang ada dalam negeri. Kemajuan teknologi adalah salah satu dampak dari globalisasi yang saat ini dapat melunturkan rasa nasionalisme 
seseorang, karena banyak sekali yang menyalahgunakan kemajuan teknologi tersebut. Setelah mengetahui penyebab rendahnya rasa nasionalisme mahasiswa program studi PPKn UNBAJA semester II dan IV tahun ajaran 2017-2018, maka selanjutnya adalah membahas mengenai peran dosen mata kuliah PPKn dalam meningkatkan rasa nasionalisme mahasiswa program studi PPKn UNBAJA semester II dan IV tahun ajaran 2017-2018.

Berdasarkan hasil observasi yang diperoleh penulis, dosen mata kuliah PPKn sangat berperan dalam meningkatkan rasa nasionalisme mahasiswa program studi PPKn UNBAJA semester II dan IV tahun ajaran 2017-2018 dalam kegiatan belajar mengajar di kelas. Dengan adanya kemampuan dosen yang berkualitas dalam menyampaikan materi PPKn dan menggunakan metode yang sangat tepat dan menarik, maka mahasiswa program studi PPKn UNBAJA semester II dan IV tahun ajaran 2017-2018 sangat antusias dalammengikuti kegiatan belajar PPKn. Selain itu, dari hasil observasi yang diperoleh, terdapat beberapa dosen yang mengajak mahasiswa berdo'a sebelum memulai kegiatan pembelajaran PPKn. Ini adalah salah satu bukti bahwa, mahasiswa program studi PPKn semester II dan IV sudah mencerminkan sikap beriman dan bertaqwa juga mencerminkan nilainilaiyang terdapat dalam Pancasila, dan membiasakan diri berpakaian batik pada setiap hari rabu untuk menjaga dan melestarikan budaya dalam negeri. Dosen sebagai pengajar sekaligus sebagai pendidik memiliki tanggung jawab besardalam menghasilkan generasi yang berkarakter, berbudaya dan bermoral. Dosen merupakanteladan bagi mahasiswa dan memiliki peran yang sangat besar dalam pembentukan karakter mahasiswa. Dosen sebagai pendidik professional memiliki empatkompetensi dasar dengan tugas utama mendidik, mengajar, membimbing, mengarahkan, melatih, menilai, dan mengevaluasi peserta didik. Disamping itu menyebutkan bahwa perilaku mengajar dosen yang baik dalam proses belajar mengajar di kelasdapat ditandai dengan adanya kemampuan penguasaan materi pelajaran, kemampuan penyampaian materi pelajaran, keterampilan pengelolaan, kelas, kedisiplinan, atusiasme, kepedulian, dan keramahan dosen terhadap mahasiswa. Melalui pendidikan formal, dosen sangat berperan untuk membangun tingkat intelektual mahasiswa. Dengan berkualiatsnya seorang dosen, maka akan terciptalah mahasiswa yang berkualitas pula. Peran seorang dosen yang berkualitas, bukan hanya sebagai sumber utamailmu pengetahuan atau jawaban dari 
segala persoalan, namun sebagai sarana dan fasilitator dalam menghubungkan mahasiswa dengan ilmu pengetahuan, sehingga kompetensi yang baik dari seorang dosen sangat diperlukan. Kampus sebagai lembaga pendidikan formal merupakan komponen yang sangatpenting dalam mengembangkan sikap nasionalisme mahasiswa.

Karena didalam kelas mahasiswa dibelajarkan tentang sikap cinta dan bangga terhadap tanah air untuk, selain itu para mahasiswapun menggunakan baju batik setiap hari rabu untuk mengenang melestarikan salah satu budaya bangsa ini. Pembiasaan penggunaan Bahasa Indonesia yang baik dan benar dalam pergaulan sehari hari, mengimplementasikan nilai-nila luhur agama dan nilai-nilai Pancasila. Peran dosen PPKn dalam mengembangkan sikap nasionalisme mahasiswa salahsatunya yaitu mengimplementasikan kegiatan transfer peserta didik yang bermoral dan memegangteguh semangat nasionalisme. Penguatan nasionalisme dimulai dengan mengembalikan jatidiri mahasiswa agar terbentuk pribadi yang berakhlak mulia. Membangun jati diri adalah membangun karakter. Upaya dosen PPKn dalam mengembangkan sikap nasionalisme mahasiswa adalah dengan menumbuhkan sikap semangat persatuan dan kesatuan, bertanggung jawab, percaya pada diri sendiri dan sikap disiplin terlebih dahulu melalui tahap-tahap perencanaan, penyiapan, sampai pada pelaksanaan proses kegiatan pembelajaran. Selain dengan upayatersebut dosen mata kuliah PPKn juga selalu bekerja sama dengan dosen mata pelajaran lain, kemahasiswaan, Kaprodi, dan orang tua mahasiswa. Dengan demikian, peran dosen menjadi sangat penting, khusus dosen mata kuliah PPKn. Dosen PPKn memiliki peranan besar dalam membimbing, mengarahkan, serta membentuk moral, sikap,dan perilaku mahasiswa menjadi berkarakter demi kemajuan bangsa.

Dosen PPKn sebagai pembimbing memberikan nasihat-nasihat dan bantuan kepada mahasiswa serta mendampingi mahasiswa saat melakukan proses belajar mengajar. Dosen PPKn sebagai agen moral memberikan pendidikan moral melalui strategi pembiasaan, keteladanan, penghargaan, dan teguran. Nilai karakter yang diperoleh mahasiswa adalah religius, tanggung jawab, berani, disiplin, jujur, santun,dan sopan.

Dosen PPKn sebagai motivator memberikan pembelajaran yang tidak monoton mencontohkan kisah orangorang sukses, dan memberikan semangat dengan kata-kata yang menggugah. Dosen PPKn mendidik dan mengembangkan 
nilai karakter yaitu pantang menyerah, berani, kreatif, dan tanggung jawab. Tugas dosen adalah mengajar dan mendidik tugas ini merupakan faktor penting dalam terlaksananya proses pendidikan.

Berhasil atau tidaknya tugas tersebut sangat tergantung pada kemampuan untuk memahami dan ketepatan memilih metode yang digunakan, sebab metodeatau cara yang digunakan banyak berperan dan menentukan sebagai penunjang keberhasilan dalam proses belajar mengajar.

Metode yang digunakan dalam mengajar PPKn dilakukan secara sadar, teratur dan bertujuan untuk menyampaikan bahan pelajaran kepada mahasiswa. Dengan proses penyampaian itu diharapkan terjadi perubahan sikap dan perubahan mahasiswa sesuai dengan tujuan yang ditentukan dalam kurikulum. Dalam pelaksanaan pengajaran PPKn di sekolah, metode yang dipergunakan berbeda dengan metode pada mata kuliah yang lain, sebab mata kuliah PPKn mempunyai kedudukan dan ciri-ciri yang khas dalam arti bahwa PPKn sebagai tuntunan hidup bukan semata-mata untuk diketahui, melainkan juga untuk menimbulkan perubahan sikap dan perbuatan yang sesuai dengan PPKn. Dari hasil wawancara dengan dosen PPKn UNBAJA dikatakan bahwa dalam proses belajar mengajar PPKn, seorang dosen
PPKn harus menggunakan metodeyang sesuai dengan tujuan dan sifat bahan,maka dapat diharapkan dosen akan lebih berhasil. Penggunakan metode ini perlu ditekankan, mengingatadanya kecenderungan sebagian besar dosen untuk mengajar dengan satu metode mengajar saja, misalnya ceramah.

Dengan demikian seorang dosen diharapkan menguasai berbagai metode mengajar yang sesuai dan sejalan dengan bahanpelajaran yang akan diajarkan sehingga menimbulkan ketertarikan pada mahasiswa untuk mempelajari pelajaran tersebut secara lebih mendalam sehingga nantinya dapat meningkatkan prestasi belajar pada diri mahasiswa itu sendiri.

\section{KESIMPULAN}

Dari hasil penelitian yang penulis lakukan mengenai peran dosen mata kuliah PPKn dalam meningkatkan rasa nasionalisme mahasiswa program studi PPKn UNBAJA semester II dan IV tahun ajaran 2017 2018 dapat di simpulkan bahwa :

1. Penyebab rendahnya rasa nasionalisme mahasiswa program studi PPKn UNBAJA semester II dan IV ajaran 2017-2018 di pengaruhi oleh beberapa faktor, yaitu :

A. Faktor internal, seperti :

1)Tidak ada kemauan dari diri mahasiswa sendiri untuk 
mengetahui dan memahami nasionalisme.

2) Rendahnya semangat belajar pada diri siswa, tidak adanya motivasi diri, tidak adanya kemauan untuk menggali diri.

3) Rendahnya pengetahuan terhadap pendidikan, serta bersikap individualis.

B. Faktor eksternal, seperti :

1) Kurangnya keteladanan atau contoh penerapan yang diberikan oleh orang tua tidak mencerminkan memiliki rasa nasionalisme yang dapat berpotensi besar di contoh oleh anggota keluarga lainnya.

2) Lingkungan masyarakat yang tidak mencerminkan rasa nasionalisme.

3) Pengaruh globalisasi yang dirasa sangat besar dampaknya pada keadaan sekarang ini dapat mengancam jati diri bangsa.

4) Kebiasaan berpakain mencontoh budaya asing yang belum tentu sesuai dengan budaya yang ada dalam negeri.

5) Kemajuan teknologi yang saat ini dapat melunturkan rasa nasionalisme seseorang.

2. Peran penting dosen mata kuliah PPKn dalam meningkatkan rasa nasionalisme mahasiswa program studi PPKn UNBAJA semester II dan IV tahun ajaran 2017-2018. Dosen PPKn UNBAJA menerapkan sebelum memulai kegiatan pembelajaran PPKn, semuanya wajib berdoa. Ini adalah salah satu bukti bahwa, mahasiswa program studi PPKN semester II dan IV sudah mencerminkan sikap beriman dan bertaqwa juga mencerminkan nilainilai yang terdapat dalam Pancasila, membiasakan diri berpakaian batik pada setiap hari rabu untuk menjaga dan melestarikan budaya dalam negeri.

\section{DAFTAR PUSTAKA}

\section{Buku:}

Arikunto, S. (2010).Prosedur Penelitian Suatu Pendekatan Praktik. Jakarta : Rineka Cipta.

Hamidi, J. \& Mustafa Lutfi (2010).Civic Education.Jakarta : Pt. Gramedia Pustaka Utama.

Latif, Y. (2017). Negara Paripurna Historitas, Rasionalitas, dan Aktualitas PancasilaI. Jakarta : Gramedia Pustaka Utama.

Moleong, L.J. (2013). Metodologi Penelitian Kualitatif Edisi Revisi. Bandung : Remaja Rosda Karya.

Pimpinan MPR dan Badan Sosialisasi MPR RI Periode 2014-2019. (2017). Materi Sosialisasi Empat 
Pilar MPR RI. Jakarta : Sekretariat Jendral MPR RI.

Sugiyono. (2013). Metode Penelitian

Pendidikan Pendekatan Kuantitatif,
Kualitatif, dan R\&D.

Undang - Undang Nomor 14 Tahun 2005 tentang Guru dan Dosen ; Lembaran Negara Republilk Indonesia. Tahun 2005 No 15. 